\title{
PENERIMAAN INFORMASI MELALUI DIGITAL TALKING BOOK OLEH SISWA TUNANETRA
}

\section{INFORMATION RECEPTION THROUGH DIGITAL TALKING BOOK BY VISUALLY- IMPAIRED STUDENT}

\author{
Tuti Alawiyah ${ }^{1}$, Ibnu Hamad ${ }^{2}$ \\ ${ }^{1}$ Departemen IImu Komunikasi, Fakultas IImu Sosial dan IImu Politik,Universitas Indonesia \\ 2Pengajar Departemen IImu Komunikasi, Fakultas IImu Sosial-IImu Politik, Universitas Indonesia \\ tuti.alawiyah@kemdikbud.go.id dan ihamad966@gmail.com
}

Diterima : 21 Maret 2017, dikembalikan untuk direvisi : 28 Maret 2017, disetujui : 12 April 2017

\begin{abstract}
Abstrak: Penelitian ini mengkaji tentang bagaimana penerimaan informasi melalui media pembelajaran Digital Talking Book oleh siswa tunanetra. Pada intinya, penerimaan informasi adalah mengubah pesan ke dalam bentuk yang dapat digunakan untuk memandu perilaku manusia. Penelitian ini dilakukan dengan menggunakan metode studi kasus. Informan adalah salah satu siswa tunanetra di sekolah inklusi MTsN 19 Jakarta. Hasil penelitian menunjukkan bahwa penerimaan informasi melalui Digital Talking Book di kalangan siswa tunanetra mempunyai tantangan tersendiri. Dalam tahapan penyeleksian informasi, informan menggunakan sumber informasi dari Braille dan Digital Talking Book secara bergantian sesuai dengan kebutuhan. Dalam tahapan interpretasi informasi, informan menafsirkan konten Digital Talking Book dengan bantuan catatan dalam huruf Braille. Dalam tahapan retensi memori, informan mampu mengingat secara baik informasi yang bersifat sementara, seperti kata-kata yang berupa istilah, angkaangka, dan penjelasan tentang definisi, namun memiliki keterbatasan untuk memori jangka panjang sehingga membutuhkan waktu yang lebih lama. Kecenderungannya adalah bahwa informan lebih memilih Braille dibandingkan dengan Digital Talking Book karena dianggap lebih mudah, ekonomis, dan cepat; merasa berinteraksi langsung dengan tulisan; dan penggunaan indera perabanya lebih otpimal sehingga mengingat lebih cepat.
\end{abstract}

Kata Kunci: Digital Talking Book, tunanetra, seleksi informasi, interpretasi, retensi.

\begin{abstract}
This research examines the information reception through learning media of Digital Talking Book by visually-impaired student. Information reception is basically converting messages into a form that can be used to guide human behaviour. The study was conducted with case study method. The informant is a visually impaired student at Inclusive School of State MTs 19 Jakarta.The results show that the information reception through Digital Talking Book among visually-impaired students has its own challenges. In the stage of selecting information, the informant uses the source of information from Braille and Digital Talking Book alternately as needed. In the information interpretation stage, the informant interprets the content of the Digital Talking Book assisted by notes in Braille. In the memory retention stage, the informant is able to remember well the temporary information, such as words of terms, numbers, and the explanation of the definition, but has limitations for long-term memory so that requires longer time. The tendency is that the informant prefers to use Braille rather than Digital Talking Book because it is considered to be easier, more economical, and faster; feels like directly interacting with the writings; and his touching sense utilization is more so optimum that he can remember in longer time.
\end{abstract}

Key Words: Digital Talking Book, visually-impaired, information selection, interpretation, retention. 


\section{PENDAHULUAN}

Pendidikan, termasuk di dalamnya akses terhadap informasi adalah hak dasar bagi semua anak di Indonesia, tak terkecuali anak-anak penyandang tunanetra. Kartunet sebuah portal yang digagas oleh pemuda penyandang disabilitas, menyebutkan bahwa populasi Indonesia lebih dari 237 juta orang, dan populasi anak usia sekolah (7-17 tahun) diperkirakan 49,6 juta orang. Jumlah penyandang tunanetra diperkirakan lebih dari tiga juta orang, dengan angka partisipasi sekolah sebesar 40\%. Tetapi, belum ada data yang pasti tentang jumlah anakanak penyandang low vision dan tunanetra di Indonesia (http://www.kartunet.com/simpangsiur-populasi-disabilitas-di-indonesia-1295).

Tarsidi (2005) menyebutkan lima tantangan paling signifikan yang dihadapi siswa penyandang disabilitas tunanetra di Indonesia yaitu: (1) hambatan di dalam komunitas; (2) akses terhadap bahan bacaan; (3) akses terhadap teknologi bantu; (4) orientasi dan aksesibilitas lingkungan; dan (5) dukungan keuangan. Dari kelima tantangan tersebut, ada dua hal yang paling krusial, yaitu terbatasnya akses terhadap bahan bacaan dan terhadap teknologi bantu.

Tarsidi (2005) menjelaskan bahwa selama ini akses penyandang disabilitas tunanetra terhadap bahan bacaan sangat terbatas. Mayoritas siswa dengan disabilitas tunanetra mempersiapkan catatan mereka sendiri dan mengatur sendiri layanan bacaan yang sesuai dengan kebutuhan mereka. Ketersediaan bahan baca cetak, kaset, atau buku Braille masih langka. Lebih jauh, Tarsidi mengemukakan bahwa akses terhadap teknologi bantu seperti komputer khusus tunanetra pun belum dapat dinikmati oleh seluruh siswa penyandang disabilitas tunanetra. Saat ini, kecenderungan yang terjadi adalah penggunaan disket atau CD untuk mengakses bahan bacaan.
Para penyandang tunanetra memiliki kemampuan penglihatan yang sangat terbatas sehingga menjadi persoalan tersendiri ketika para penyandang tunanetra ini harus menyerap informasi dan materi pembelajaran yang terdapat di dalam buku, meski sudah menggunakan buku Braille. Penguasaan huruf Braille menjadi kemampuan mendasar bagi peserta didik penyandang tunanetra, seperti halnya tulisan tangan untuk peserta didik yang mempunyai penglihatan normal. Namun, akses terhadap buku menjadi masalah tersendiri yang dialami oleh peserta didik penyandang tunanetra.

Saat ini, ketersediaan buku Braille menjadi persoalan tersendiri karena jumlahnya yang sangat terbatas. Berdasarkan wawancara peneliti dengan Bambang Basuki (2016), Ketua Yayasan Mitra Netra, organisasi yang peduli dengan peningkatan kualitas hidup penyandang disabilitas tunanetra, diperoleh informasi bahwa ketersediaan buku Braille dalam bahasa Indonesia saat ini baru sekitar 2.800 judul. Jumlah ini tentu masih jauh tertinggal dari jumlah buku yang dapat diakses oleh orang yang berpenglihatan normal. Jumlah yang sangat terbatas ini dikarenakan biaya produksi yang jauh lebih mahal dibandingkan dengan biaya produksi buku cetak konvensional. Dari sisi kepraktisan pun, buku Braille ini sulit untuk dibawa atau disimpan di ruang penyimpanan yang terbatas.

Berkaitan dengan masalah keterbatasan jumlah buku Braille, Basuki (2016) mengemukakan sebuah inovasi baru sebagai solusi yang memanfaatkan kemajuan teknologi informasi dan komunikasi (TIK), yaitu penggunaan media audiobook atau Digital Talking Book (DTB). Alternatif solusi inovatif ini didasarkan pada pertimbangan bahwa para penyandang tunanetra ini telah kehilangan kemampuan visualnya dan selama ini mereka hanya mengandalkan indera peraba untuk buku Braille. Dengan kondisi yang demikian ini, 
alternatif yang ditempuh adalah optimalisasi penggunaan indera pendengaran, yang salah satu di antaranya adalah media audiobook atau Digital Talking Book (DTB).

Digital Talking Book adalah buku yang dapat "berbicara" yang merupakan hasil rekaman audio dari buku-buku pelajaran yang dikemas dalam bentuk $C D$ atau file. Untuk menggunakannya, para siswa penyandang tunanetra cukup mendengarkan rekaman audio yang berisi materi pelajaran. Siswa penyandang tunanetra memungkinkan untuk mendengarkan rekaman di bab, halaman, atau paragraf tertentu, atau dapat mengulang sesuai dengan yang diinginkan. Digital Talking Book sendiri sebenarnya merupakan penyempurnaan dari model perekaman analog yang menggunakan pita kaset (talking book). Perekaman dalam bentuk kaset dianggap sudah tidak memungkinkan lagi karena dalam satu judul buku misalnya, membutuhkan jumlah kaset yang lebih banyak.

Sebuah konsorsium yang bernama "DAISY Consortium", dengan anggotanya yang terdiri dari para pakar perpustakaan-perpustakaan khusus di seluruh dunia dan perusahaanperusahaan yang bergerak dalam bidang teknologi, telah berhasil mengembangkan teknologi DTB dan membuat standarisasi dalam hal file DTB yang disebut dengan standar DAISY (Digital Audio Based-information System) www.daisy.org/about_usDAISY Consortium "About Us",) .

Di dalam DTB, informasi audio (file audio digital) disusun sedemikian rupa secara bertingkat sesuai dengan levelnya menurut format/standar DAISY, berdasarkan struktur buku aslinya. Misalnya, apabila sebuah buku terdiri dari bab, sub-bab, dan paragraf, DAISY menempatkan bab pada level yang paling tinggi dan menempatkan paragraf pada level paling rendah, dengan cara memberikan kode-kode tertentu yang dapat dibaca atau dimengerti oleh player.

File DTB direkam dengan menggunakan software recorder khusus yang diinstal ke dalam komputer personal. File ini disimpan di dalam hardisk dan dapat ditransfer ke dalam $C D$ (Compact Disc) untuk didistribusikan kepada pengguna. Generasi baru DTB ini akan menjadi media alternatif bagi tunanetra dalam mengakses berbagai informasi yang mereka butuhkan.

Kebutuhan untuk teknologi DTB tampaknya akan semakin meningkat. Sebagai gambaran tentang aksesibilitas di sektor e-book, Ken Petri (2012) memperkirakan bahwa setidaknya 5 persen, atau mungkin juga sampai 10 persen dari semua orang Amerika, memiliki semacam cacat cetak. Meskipun jumlah pengguna DTB sangatlah potensial, dan didukung oleh kemajuan teknologi di bidang talking book, namun penelitian di area ini masih sangat sedikit. Literatur tentang DTB terutama perhatian dari para pemangku kepentingan profesional dan organisasi non-profit sangat terbatas. Seringkali, perspektif yang digunakan adalah perspektif teknologi, bukan perspektif pengguna. Kondisi yang demikian inilah yang setidaknya merupakan kesan yang diperoleh selama penulisan laporan yang dihasilkan oleh peneliti asal Swedia, Lundh (2013).

Penelitian yang dilakukan oleh Fichten dkk. (2009) di Kanada menunjukkan bahwa sejauh ini beberapa bentuk e-learning memiliki aksesibilitas yang sangat baik, sementara yang lain menimbulkan kekhawatiran serius bagi siswa penyandang disabilitas yang berbeda. Meskipun siswa sangat antusias memanfaatkan e-learning, mereka juga menunjukkan bahwa mereka mengalami masalah, yang sebagian besar masih belum terpecahkan. Misalnya, adanya beberapa situs web yang tidak kompatibel dengan teknologi layar-membaca, situs web yang memiliki struktur yang membuat sulit siswa yang tidak dibekali dengan kemampuan navigasi. 
Berbagai masalah lainnya adalah yang berkaitan dengan warna, ukuran huruf, peta online, dan gambar. Tidak adanya penjelasan tentang apa yang terjadi di klip video menyebabkan masalah aksesibilitas bagi siswa tunanetra.

Memperhatikan potensi DAISY Digital Talking Book dalam mendukung proses pembelajaran anak penyandang disabilitas, Sorongon dari Autism Society Philippines (ASP) mengajukan kegiatan "Search for Innovative Philippine Human Rights Initiative" pada tahun 2011 yang kemudian dilakukan penyusunan proposal penelitiannya oleh Ateneo Human Rights Center, Ateneo School of Government, dan the Caucus of Development NGOs.

Proposal penelitian yang berjudul "Educating Children with Disabilities of Their Rights Using the Digital Books" muncul sebagai salah satu pemenang di antara lebih dari 200 proposal yang masuk. Setelah setahun pelaksanaan, 626 anakanak dengan disabilitas tunanetra, Autism Spectrum Disorder, Down Syndrome, AD/HD, Cerebral Palsy, tuli, dan cacat lainnya memperoleh pengetahuan tentang hak-hak mereka, khususnya hak atas pendidikan yang baik, hak untuk bermain, dan hak untuk dilindungi terhadap pelecehan verbal dan fisik. Dua puluh tujuh sekolah khusus dan pusat terapi di seluruh Filippina setuju untuk menjadi mitra dan berkomitmen untuk memiliki guru yang akan mendampingi anak-anak penyandang disabilitas saat melakukan aktivitas belajar.

Penelitian yang dilaksanakan mengungkapkan bahwa salah satu dampak utama dari aktivitas pembelajaran menggunakan DTB adalah dimudahkannya para guru dalam memotivasi anak penyandang disabilitas untuk aktif berpartisipasi selama diskusi dan evaluasi. Selain itu, DTB disediakan bagi anak penyandang disabilitas agar mereka memiliki kesempatan untuk berbagi pengalaman pribadi dalam kaitannya dengan hak-hak yang disajikan, belajar tanggung jawab yang melekat pada hakhak mereka, dan mencari solusi atau alternatif jika hak-hak mereka dilanggar.

Dari penjelasan yang telah dikemukakan, tampaklah bahwa penerimaan informasi oleh siswa tunanetra, baik yang berupa konten pelajaran maupun ilmu pengetahuan lainnya, menjadi hal yang sangat penting. Siswa tunanetra mempunyai keterbatasan penglihatan sehingga tidak dapat mempelajari sesuatu secara langsung tetapi mengoptimalkan kemampuan sisa indera yang mereka miliki. Penelitian ini berusaha menjelaskan proses penerimaan informasi yang dilakukan siswa tunanetra yang melewati tiga tahap, yaitu: (1) proses seleksi informasi; (2) interpretasi; dan (3) retensi informasi. Selain itu, peneliti juga mengkaji faktor-faktor apa saja yang memengaruhi penerimaan pesan dilihat dari aspek pengaruh penerima, pengaruh pesan, dan pengaruh sumber informasi.

\section{KAJIAN LITERATUR}

Penelitian ini menggunakan teori penerimaan informasi sebagai teori utama untuk menjelaskan proses penerimaan informasi melalui media belajar DTB di kalangan siswa disabilitas tunanetra yang meliputi proses penyeleksian informasi, interpretasi, dan retensi memori.

Penerimaan informasi merupakan proses yang mengubah pesan ke dalam bentuk yang dapat digunakan untuk memandu perilaku manusia. Menurut Ruben dan Stewart (2006), proses penerimaan informasi mencakup penyeleksian informasi, interpretasi, dan retensi. Dalam kehidupan sehari-hari, suatu peristiwa bisa saja nampak sederhana, tetapi pada kenyataannya melibatkan banyak faktor dalam proses yang aktif.

Penyeleksian informasi. Dalam suatu situasi, kita akan cenderung memilih satu sumber 
informasi dan mengabaikan yang lainnya. Dalam situasi yang sederhana sekalipun, kita akan cenderung membuat keputusan rumit yang tanpa kita sadari. Manusia berinteraksi dengan lingkungan yang penuh dengan sinyal dari berbagai jenis, mulai dalam bentuk isyarat visual, suara (isyarat pendengaran), sentuhan (isyarat tactile), rasa (isyarat gustatory), atau bau (isyarat penciuman). Jumlah isyarat ini sangat tak terbatas. Oleh karena itu,kita perlu memilih dan menggunakan beberapa isyarat, dan pada saat yang bersamaan, kita mengabaikan yang lainnya.

Interpretasi informasi. Interpretasi terjadi pada saat kita memaknai arti yang terjadi di sekitar kita. Interpretasi memberi makna terhadap pesan. Setiap kali orang memperhatikan pesan apapun, mereka membuat beberapa interpretasi dasar; mereka memutuskan apakah itu pesan lucu atau mengkhawatirkan, benar atau tidak benar, serius atau lucu, baru atau lama, dan bertentangan atau konsisten.

Ketika seseorang memutuskan untuk menonton sebuah program televisi atau film, misalnya, dia membuat semua penentuan ini sebagai pemirsa, sering tanpa berpikir banyak tentang proses. Memperhatikan berbagai tanda adalah salah satu komponen penerimaan pesan. Agar pesan menjadi berguna, pesan pada tandatanda juga harus ditafsirkan. Orang harus tahu persis apa arti kata-kata tersebut. Dalam semua situasi, tindakan masyarakat akhirnya akan didasarkan pada arti yang melekat pada pesan yang telah mereka pilih. Dalam menginterpretasi makna, kita sangat dipengaruhi antara lain oleh pengetahuan, latar belakang, dan cara pandang.

Retensi memori. Retensi memori memainkan peran yang sangat diperlukan dalam melakukan seleksi dan interpretasi. Kemudahan untuk mengingat informasi yang ada seringkali mengabaikan kompleksitas proses yang terlibat.
Memori memainkan peran yang sangat diperlukan dalam proses interpretasi. Manusia mampu menyimpan dan menggunakan informasi secara aktif dalam jumlah yang luar biasa, di samping dapat menemukan dan menggunakannya secara efisien.

Morton Hunt (1982) memberikan deskripsi yang sangat baik dari proses retensi yang kompleks ini dengan setiap tindakan berpikir melibatkan penggunaan gambar, suara, simbol, makna, dan hubungan antara berbagai hal. Semua hal ini disimpan di dalam memori. Organisasi memori sangat efisien sehingga seringkali kita tidak menyadari harus mengerahkan upaya untuk menemukan dan menggunakan bahan-bahan ini. Kita perlu mempertimbangkan rentang jenis informasi yang disimpan di dalam memori yang sewaktu-waktu dapat dengan mudah dipanggil kembali. Ada juga informasi yang sulit untuk dipanggil dari memori yang diakibatkan oleh berbagai faktor.

Pada tahap ini, kita sudah mampu menyimpan secara aktif informasi dalam jumlah yang banyak, di mana kita dapat mencari dan menggunakannya secara efisien. Namun ternyata, tidak semua pesan yang kita terima dapat kita ingat atau tersimpan di dalam memori ingatan kita. Informasi yang akan digunakan menjadi bagian dari apa yang disebut dengan memori jangka pendek (short-term memory). Beberapa informasi akan diproses menjadi bagian dari memori jangka panjang (long-term memory).

Short-term memory adalah suatu sistem di otak manusia yang berfungsi menyimpan informasi yang bersifat sementara, misalnya pada saat manusia mencoba hal yang baru atau mencoba mengelompokkan informasi yang diterima. Kemudian, long-term memory adalah suatu sistem di otak manusia yang berfungsi untuk menyimpan informasi secara permanen, mengatur, dan memanggil kembali informasi 
tersebut pada saat dibutuhkan di masa yang akan datang.

Menurut Ruben dan Stewart (2006), banyak faktor yang memengaruhi proses pemilihan pesan, interpretasi, dan retensi pesan. Sejauh mana pengaruh faktor-faktor ini terhadap proses penerimaan pesan tergantung pada kondisi individu sebagai penerima pesan di samping tergantung juga pada sifat pesan dan sumber, media, dan lingkungan. Berikut ini akan diuraikan 4 faktor yang memengaruhi penerimaan pesan.

Pengaruh kondisi individu sebagai penerima pesan (receiver influences). Dalam situasi apapun, tujuan (goal) memiliki pengaruh yang besar pada penerimaan pesan, baik yang berkaitan dengan tujuan jangka pendek maupun jangka panjang, baik yang sifatnya berkaitan dengan agenda pribadi maupun pekerjaan, sangat berpengaruh terhadap proses penerimaan pesan.

Kemampuan (capability) individu penerima pesan yang berbeda-beda menyebabkan perbedaan pada pola penerimaan pesan. Sebagai contoh, misalnya: kemampuan bahasa. Kemungkinan penerimaan pesan dan probabilitas dari individu bilingual jauh lebih luas daripada seseorang yang berbicara hanya satu bahasa. Untuk alasan yang sama, orang-orang yang terlatih dalam bidang profesional dan teknis tertentu memiliki akses ke bahan dan dokumen; sedangkan yang lainnya tidak. Individu yang memiliki kemampuan khusus terhadap pesan tertentu akan turut memengaruhi proses pemilihan, interpretasi, dan retensi pesan.

Gaya komunikasi individu (communication style) yang berbeda-beda sering menyebabkan perbedaan dalam proses penerimaan pesan. Umumnya, orang-orang yang memiliki gaya komunikasi yang sangat verbal (yaitu, yang berbicara panjang lebar tentang pikiran dan pendapat mereka sendiri) cenderung memiliki paparan informasi yang kurang diproduksi oleh orang lain dalam situasi interpersonal. Oleh karena itu, gaya komunikasi seseorang dapat memengaruhi proses penerimaan pesan sehingga dapat membatasi kontribusi dari yang lain.

Pengalaman dan kebiasaan (experience and habit) adalah kekuatan yang besar dalam penerimaan pesan. Pengalaman belajar yang dimiliki sebelumnya akan memengaruhi pola penerimaan informasi sehingga ada kemungkinan individu akan melakukan pengulangan. Oleh karena itu, kebiasaan dan perilaku yang dimiliki individu sebelumnya akan menjadi pengaruh yang penting dan prediktor perilaku dalam penerimaan informasi masa depan.

Pengaruh pesan (message/information influencer). Ruben dan Stewart (2006) menyebutkan dalam banyak situasi bahwa orang memiliki pilihan untuk menerima dan menggunakan pesan, baik ada maupun tidak adanya alternatif pengaruh yang signifikan pada penerimaan pesan. Pesan-pesan alternatif mungkin lebih mudah atau bahkan mungkin lebih sulit untuk diterima, ditafsirkan, dan dipertahankan.

Seseorang yang memiliki preferensi untuk satu pendekatan di atas yang lain dipengaruhi oleh gaya pribadi, pengalaman masa lalu, dan faktor lainnya.

Pengaruh sumber pesan (source influencer). Ketika sumber dianggap kredibel dan berwibawa, pesan mereka cenderung menarik perhatian yang lebih dibandingkan dengan pesan-pesan yang berasal dari orang-orang yang tidak dianggap kredibel atau otoritatif. Karakteristik ini juga cenderung memengaruhi interpretasi dan retensi pesan. Kadang-kadang, kredibilitas sumber juga dipengaruhi oleh keahlian khusus yang dimilikinya terkait topik tertentu. Sebagai contoh, seorang pialang saham dapat dianggap sebagai sumber informasi yang baik pada industri pasar saham. Dalam kasus lain, kredibilitas 
individu mungkin mencakup sejumlah mata pelajaran karena kombinasi pendidikannya.

Cara pengemasan dan penyampaian pesan juga memengaruhi proses pemilihan pesan, interpretasi, dan retensi. Dalam kasus pesan lisan, volume berbicara, pitch, pengucapan, aksen, dan penggunaan jeda dapat memengaruhi komunikasi. Isyarat visual seperti gerak tubuh, ekspresi wajah, dan kontak mata juga dapat menjadi faktor yang signifikan.

\section{Media Pembelajaran}

Pada awal sejarah pembelajaran, media merupakan alat bantu yang digunakan guru untuk menerangkan materi pelajaran. Alat bantu yang mula-mula digunakan adalah alat bantu visual, yaitu berupa sarana yang dapat memberikan pengalaman visual kepada siswa, yang antara lain tujuannya adalah untuk meningkatkan motivasi belajar, memperjelas dan mempermudah konsep yang abstrak, dan mempertinggi daya serap atau retensi belajar.

Dengan berkembangnya teknologi, khususnya teknologi audio, pada pertengahan abad ke-20, lahirlah alat bantu audio visual yang terutama menggunakan pengalaman yang konkret untuk menghindari verbalisme. Pada akhir tahun 1950, teori komunikasi mulai memengaruhi penggunaan media sehingga fungsi media selain sebagai alat bantu, juga berfungsi sebagai penyalur pesan.

Dengan menganalisis media melalui bentuk penyajian dan cara penyajiannya, terdapat tujuh kelompok media menurut Bretz dalam Hujair (2009) yaitu: (1) grafis/bahan cetak/gambar diam; (2) media proyeksi diam; (3) media audio; (4) media audio visual diam; (5) media gambar hidup/film; (6) media televisi; dan (7) multimedia. Digital Talking Book termasuk ke dalam kategori kelompok ketiga yaitu media audio dengan spesifiksi media alat perekaman.
Media audio adalah media yang penyampaian pesannya hanya dapat diterima oleh indera pendengaran. Pesan atau informasi yang akan disampaikan dituangkan ke dalam lambang-lambang auditif berupa kata-kata, musik, dan sound effect. Alat perekam sendiri merupakan media yang menyajikan pesannya melalui proses perekaman; tidak seperti radio yang menggunakan gelombang elektromagnetik sebagai alat pemancarnya.

Kelebihan media alat perekam adalah dapat diputar berulang-ulang sesuai dengan kebutuhan siswa, sangat efektif untuk pembelajaran bahasa, dan penggandaan program yang sangat mudah. Sementara itu kelemahannya adalah daya jangkau yang sangat terbatas.

\section{METODE PENELITIAN}

Penelitian ini menggunakan paradigma postpositivis di mana paradigma ini lahir sebagai koreksi atas kelemahan yang ada dalam paradigma positivis. Paradigma postpositivis menolak gagasan bahwa fenomena sosial dapat dipelajari melalui cara yang objektif dan bebas nilai. Esensi dari paradigma postpositivis adalah realisme kritis. Paradigma postpositivis mengganggap bahwa peneliti tidak bisa mendapatkan fakta dari suatu kenyataan jika peneliti mempunyai jarak dengan kenyataan itu sendiri.

Menurut Guba dan Lincoln dalam Denzin dan Lincoln (1994), paradigma postpositivis secara ontologi adalah sebuah realis kritis, di mana realitas itu memang ada tetapi tidak dapat dipahami secara sempurna karena mekanisme intelektual manusia yang pada dasarnya sulit dikendalikan oleh fenomena. Secara epistemologi, paradigma ini merupakan modifikasi objektivis, di mana objektivitas sangat ideal tetapi pada kenyataannya tidak selalu dapat diterima oleh pikiran orang lain. Secara metodologi, postpositivis menekankan pada 
penelitian yang bertujuan untuk mendapatkan lingkungan yang lebih alami, mengumpulkan informasi yang lebih situasional dan mendapatkan temuan sebagai elemen dalam penelitian.

Penelitian ini bertujuan untuk mengamati dan mendapatkan gambaran proses penerimaan informasi yang dilakukan oleh siswa tunanetra melalui tiga tahap, yaitu proses seleksi informasi, interpretasi, dan retensi informasi. Selain itu, peneliti juga mencoba mendalami faktor-faktor yang memengaruhi penerimaan pesan dilihat dari aspek pengaruh penerima, pengaruh pesan, dan pengaruh sumber informasi.

Peneliti menggunakan pendekatan kualitatif untuk menjawab pertanyaan penelitian deskriptif tentang bagaimana proses penerimaan informasi pada siswa tunanetra melalui media belajar DTB dengan pendekatan teori penerimaan informasi. Hal ini sejalan dengan pemikiran Neuman (1997) yang mengemukakan bahwa orientasi dalam penelitian kualitatif yaitu peneliti memfokuskan dirinya pada makna subjektif, pendefinisian, metapora, dan deskripsi pada kasus-kasus yang spesifik. Selain itu, sangat dimungkinkan juga untuk menempuh langkah-langkah penelitian yang non linear, di mana penelitian kualitatif memberikan ruang bagi peneliti untuk "kembali" pada langkah-langkah penelitian yang sudah ditempuhnya dalam menjalani proses penelitian.

Strategi yang digunakan untuk penelitian ini adalah studi kasus. Strategi ini digunakan karena pertanyaan penelitian berkaitan dengan how atau why. Studi kasus lebih dipahami sebagai pendekatan untuk mempelajari dan menginterpretasi suatu kasus dalam konteksnya yang alamiah tanpa adanya intervensi dari pihak luar. Studi kasus menurut Neuman (2006) dapat dilakukan oleh individu, kelompok, organisasi, kelompok kepentingan, atau unit berdasarkan letak geografi.
Teknik pengumpulan data dalam penelitian ini dilakukan melalui wawancara mendalam (in depth interview), observasi, dan studi dokumentasi. Di samping itu, peneliti juga menggunakan wawancara semi terstruktur karena peneliti ingin mendalami permasalahan secara lebih terbuka, di mana informan (siswa disabilitas tunanetra) akan dimintai pendapat, perasaan, dan pengalamannya selama mengikuti kegiatan pembelajaran melalui penggunaan teknologi DTB. Informan yang dipilih sebagai sumber data di dalam penelitian ini adalah seorang siswa tunanetra dari sekolah inklusi MTsN 19 Jakarta. Profil informan adalah berusia 15 tahun, tunanetra sejak lahir, memiliki keluarga inti yang semuanya penyandang tunanetra, dan sebagai anggota perpustakaan khusus untuk tunanetra yang berada di Yayasan Mitranetra, Jakarta.

\section{HASIL DAN PEMBAHASAN}

\section{Penerimaan Informasi}

Prinsip dari penerimaan informasi adalah mengubah pesan yang masuk ke panca indera manusia menjadi bentuk yang dapat digunakan untuk memandu perilaku manusia. Sebelum ada DTB sebagai sumber belajar, para penyandang disabilitas tunanetra menggunakan buku Braille sebagai media belajar. Keberadaan buku Braille sendiri tidak dapat dipisahkan dengan penggunaan DTB saat ini.

Proses penyeleksian informasi dimulai saat informan menjadikan buku Braille sebagai sumber informasi. Informan menggunakan buku Braille untuk pertama kalinya adalah pada saat informan bersekolah di Sekolah Dasar Luar Biasa (SDLB). Pada saat itu, buku Braille menjadi satu-satunya pilihan sumber belajar karena dianggap berisikan kemampuan dasar bagi siswa tunanetra untuk belajar. Fokus pembelajaran adalah pengenalan abjad $A B C D$ 
dan seterusnya, serta tanda baca, seperti: tanda tanya, tanda seru, kurung buka dan kurung tutup, titik dua dan titik koma, dan pengenalan huruf Braille Arab untuk membaca Alquran.

Saat pertama kali belajar menggunakan buku Braille, informan merasa kesulitan dalam memahami konsep penghafalan dan pengepasan titik sebagai penanda huruf. Dibutuhkan pembiasaan untuk teratur belajar buku Braille. Dalam mempelajari kemampuan dasar Braille ini, informan membutuhkan waktu sekitar satu tahun. Saat informan bersekolah di SDLB, informan menggunakan Braille untuk semua mata pelajaran, meski terbatas jumlahnya, baik koleksi buku yang kurang lengkap, penempatan buku Braille yang kurang rapi, buku Braille yang hilang, maupun cetakan buku Braille yang kadang-kadang datang terlambat.

Informan mengenal konsep DTB sejak duduk di kelas 4 SD yang pada saat itu belum berformat seperti $D T B$, tetapi masih berbentuk pita kaset. Pada awalnya, informan merasa heran mengapa kegiatan belajar tidak menggunakan buku Braille seperti biasanya tetapi justru menggunakan perangkat/alat yang terbilang baru bagi informan.

Mengingat informan sudah terbiasa dari sejak kecil belajar melalui media kaset audio, informan tidak membutuhkan waktu adaptasi yang lama untuk menggunakan DTB. Kelebihan DTB adalah bahwa siswa dapat dengan mudah berpindah ke halaman atau bab tertentu sesuai dengan keinginannya. Sekalipun kondisi yang demikian ini memudahkan informan belajar karena pada saat mencari halaman tertentu sangat terbantu, informan tetap saja merasa lebih aman dan nyaman apabila membaca langsung menggunakan buku Braille.

Setelah mengenal buku Braille dan DTB, informan merasa bahwa penggunaan kedua jenis media pembelajaran tersebut sangat bergantung pada situasi. Misalnya saat belajar matematika, akan lebih mudah jika menggunakan Braille karena perabaan itu lebih bagus dan mempercepat penghafalan; tetapi untuk pelajaran bahasa seperti bahasa Indonesia atau bahasa Inggris, lebih mudah memahaminya jika dipelajari melalui DTB, dengan catatan bahwa pengucapan atau pelafalan harus benarbenar baik agar dapat membantu pemahaman.

Informan membedakan kegiatan belajar melalui buku Braille dengan kegiatan belajar melalui DTB sebagaimana yang disajikan berikut ini.

Belajar melalui buku Braille memakai indera peraba; tetapi belajar melalui DTB menggunakan indera pendengaran. Penggunaan buku Braille lebih nyaman dan lebih efisien karena lebih mudah, ekonomis, dan cepat. Dalam penggunaan $D T B$, ada sedikit kesulitan karena informan hanya mendengarkan orang bicara tentang materi pelajaran; sedangkan dengan buku Braille, informan berinteraksi langsung dengan tulisan sehingga kegiatan belajar dirasakan lebih mengena.

DTB ada untuk mengatasi keterbatasan buku Braille. Tidak semua buku ditulis dalam versi Braille karena butuh proses yang relatif lama untuk memproduksinya. Tidak demikian halnya dengan pembuatan/produksi DTB.

Ketika masih belajar di TK dan kelas rendah $\mathrm{SD}$, informan masih berusaha menggunakan huruf alfabet biasa, dan beberapa materi yang bisa dilihat secara terbatas bisa langsung direkam di otak sehingga daya ingat dapat lebih cepat. Menurut informan, response audio lebih lambat dibandingkan dengan response visual. Sebagai contoh, pada saat informan mencoba menghafal Alquran melalui youtube (dengan konsep yang sama seperti DTB, informan menghafal dengan cara mendengarkan orang lain membacakan Alquran), informan merasa prosesnya menjadi lebih lambat dibandingkan dengan informan belajar menghafal dengan membaca sendiri Alquran Braille. Informan 
merasa penginderaannya lebih bagus untuk perabaan.

Sebelum ada DTB, informan belajar melalui buku Braille untuk semua materi pelajaran. Hampir tidak ada materi pelajaran yang sulit dipahami jika memakai Braille. Belajar melalui Braille, indera peraba informan justru dapat lebih optimal digunakan sehingga kemampuan mengingatnya juga lebih cepat. Dapat diumpamakan seperti orang berpenglihatan normal tetapi mempunyai indera penglihatan yang lebih baik untuk mengingat.

Diakui bahwa belajar melalui buku Braille mempunyai kelemahan jika digunakan untuk membaca tulisan yang agak panjang di mana tangan akan terasa pegal karena harus terus bergerak dan membutuhkan konsentrasi tinggi. Dengan demikian, ada batasan waktu tertentu bagi informan untuk membaca dengan menggunakan buku Braille.

Materi pelajaran yang spesifik yang hanya dapat dipahami dengan menggunakan Braille adalah materi pelajaran yang mengandung banyak rumus, seperti yang terdapat pada pelajaran matematika dan fisika. Meskipun penggunan DTB tetap memungkinkan, hal ini memiliki banyak kelemahan. Materi pelajaran yang dirasakan agak sulit dipahami jika menggunakan DTB adalah mata pelajaran bahasa asing karena biasanya pengucapan dan penulisannya berbeda.

Informan lebih memilih buku Braille untuk belajar materi pelajaran yang banyak menggunakan simbol seperti dalam pelajaran matematika. Misalnya, pembacaan " $(2 x+3 y)$ " melalui DTB dirasakan agak membingungkan dan menyulitkan. Jika hal yang sama disajikan dengan menggunakan huruf Braille, informan akan dapat lebih mudah memahaminya.

Dalam tahapan penyeleksian dan pemilihan akses terhadap sumber informasi, informan lebih cenderung memilih untuk tetap menggunakan buku Braille dibandingkan dengan DTB karena ada interaksi informan melalui sentuhan sehingga dirasakan lebih mengena dan membuat informan memahami pesan yang disampaikan.

Untuk memahami dan menafsirkan materi pelajaran tertentu, informan menghafalnya dengan cara membaca Braille atau mendengarkan DTB secara berulang. Jika mempelajari materi pelajaran yang mengandung banyak rumus, informan akan secara simultan mencatatnya menggunakan huruf Braille disertai harapan untuk dapat mengingat lebih cepat. Informan menyukai pelajaran bahasa Indonesia karena dianggap tidak terlalu sulit dan sudah terbiasa mendengarkan cerita novel dan suka menulis.

Kesukaan informan dalam membaca dan menulis cerita memengaruhi daya ingatnya sehingga dapat memahami pelajaran bahasa Indonesia lebih cepat. Sementara itu, untuk penggunaan $D T B$, informan menyukai bahasa asing, sejarah, IPS, dan cerita. Ada pengaruh besar dari keluarga, di mana ibu informan seringkali membacakan cerita dan mempunyai hobi menulis.

Proses retensi (memori) berperan penting dalam melakukan seleksi dan interpretasi pesan. Manusia mampu menyimpan informasi dan menggunakannya secera aktif di waktu yang tak terduga. Di tahap ini, untuk ingatan jangka pendek (short-term memory), informan mempunyai ingatan yang baik dalam mengingat materi pelajaran terutama kata-kata sulit yang dibaca atau didengarkan melalui DTB. Sekalipun demikian, dalam mengingat materi pelajaran untuk jangka waktu yang lama (long-term memory), informan tidak dapat mengingat jika hanya dengan sekali baca atau sekali dengar. Dibutuhkan berapa kali pengulangan tergantung situasi dan mood informan. Rata-rata informan harus mengulang dua sampai tiga kali. 
Jenis mata pelajaran eksak atau non-eksak juga berpengaruh. Untuk pelajaran non-eksak, karena materi pelajarannya lebih bersifat umum, lebih mudah untuk dihafal dibandingkan dengan materi pelajaran eksak. Untuk materi pelajaran eksak, meski sudah ada Braille atau DTB, informan tetap saja membutuhkan bantuan guru atau teman untuk lebih memperjelas materi pelajaran karena keterbatasannya pada saat mengonversi catatan di kelas menjadi Braille yang membutuhkan waktu dan penjelasan.

Saat menghadapi ujian atau tes di sekolah, informan lebih suka belajar menggunakan Braille jika waktunya berdekatan dengan waktu ujian. Alasannya adalah karena kebiasaan saja. Jika waktu belajar dekat dengan waktu ujian, materi pelajaran yang dipelajari dapat lebih mudah diingat. Berbeda dengan belajar melalui DTB di mana informan tidak bisa belajar dalam waktu yang singkat karena keterbatasan media audio yang membuat informan tidak bisa menangkap materi pelajaran dengan cepat.

Untuk materi pelajaran ilmu-ilmu sosial, informan merasa lebih nyaman dan cepat memahami jika menggunakan DTB. Untuk materi pelajaran ilmu-ilmu eksak, lebih nyaman menggunakan Braille karena menggunakan simbol-simbol sehingga lebih mudah diterapkan dan dibayangkan oleh informan saat menggunakan Braille.

Selanjutnya, di antara berbagai faktor yang memengaruhi penerimaan pesan, salah satunya adalah tujuan yang akan dicapai seseorang sewaktu mengakses infomasi. Informan merasa sudah cukup dengan keberadaan Braille dan DTB sebagai media pembelajaran.

Penggunaan DTB sangat membantu informan untuk mempercepat pemahaman materi pelajaran sehingga sewaktu mengikuti kegiatan pembelajaran di kelas, informan dapat mengejar ketertinggalan dengan teman-teman lainnya yang berpenglihatan normal. Informan bersekolah di sekolah inklusidi mana di sekolah ini, metode pembelajaran berlaku sama untuk semua anak termasuk anak-anak berkebutuhan khusus. Kondisi yang demikian ini menjadi tantangan tersendiri bagi informan untuk beradaptasi dengan siswa-siswa lain yang berpenglihatan normal.

Pada umumnya, cara penyampaian informasi/pesan turut memengaruhi proses pemilihan pesan, interpretasi, dan retensi. Namun, ternyata informan tidak terlalu mempermasalahkan cara pengemasan dan penyampaian pesan. Misalnya, dari jenis suara yang ada di dalam DTB tidak terlalu berpengaruh terhadap pemahaman atau mood dalam belajar karena informan lebih mementingkan materi pelajaran yang ada di dalamnya. Informan beranggapan bahwa elemen penting dalam penyampaian pesan di dalam DTB adalah pengucapan yang jelas dari lafal $A B C D$, pembacaan yang cepat lebih disukai, dan bahasa yang digunakan adalah bahasa baku. Jika yang digunakan adalah bahasa sehari-hari, ada kemungkinan bisa menimbulkan perbedaan arti.

Saat belajar melalui DTB, informan merasa lebih santai. Jika pelajaran yang sifatnya pengulangan, informan bisa belajar sambil tiduran, bahkan sambil melakukan sesuatu, seperti makan. Namun, untuk pelajaran yang dianggap penting dan harus dicatat, informan harus dalam posisi duduk dan berkonsentrasi.

DTB membutuhkan perangkat khusus saat digunakan. Namun hal itu hanya dapat dilakukan jika informan menggunakannya di perpustakaan Mitranetra. Untuk penggunaan di rumah, informan menggunakan laptop yang dilengkapi software khusus pemutar DTB. Sejauh ini, informan tidak membutuhkan bantuan orang lain untuk mengoperasikan DTB karena sudah paham cara penggunaannya dan tidak terlalu mengalami hambatan yang berarti. 
Informan terlahir sebagai tunanetra low vision dengan tingkat penglihatan yang semakin lama semakin menurun. Informan mempunyai saudara laki-laki dan orang tua yang sama-sama tunanetra yang selalu mendukung meski tidak mendampingi belajar secara intens karena keterbatasan masing-masing. Sewaktu informan masih kecil, orang tuanya masih mendampingi dengan cara membacakan buku-buku cerita Braille.

Dewasa ini, perkembangan teknologi telah banyak membantu informan dalam mencari pengetahuan. Misalnya, melalui pemakaian handphone yang dilengkapi dengan screen reader yang berarti informan tidak hanya terpaku dengan Braille saja tetapi justru semuanya saling mengisi dan melengkapi sehingga membuat belajar menjadi lebih efektif, mudah, dan optimal. Penggunaan DTB dan Braille tergantung pada situasi dan kondisi. Ada kalanya Braille lebih baik daripada $D T B$ tetapi ada kalanya juga DTB justru lebih baik daripada Braille. Pada dasarnya, kedua media ini dinilai saling mengisi dan saling melengkapi. Untuk saat ini, informan merasa bahwa jika hanya belajar melalui buku-buku Braille dan DTB dinilai tidak cukup memadai sehingga diperlukan upaya pemutakhirannya (updating). Untuk kepentingan ini, informan mencari informasi terbaru melalui mesin pencari Google dengan menggunakan handphone yang membawa konsep hampir seperti DTB. Handphone yang digunakan tunanetra memiliki screen reader yang memungkinkan untuk membaca apa yang ada di layar sehingga menjadi hampir menyerupai DTB.

Keberadaan buku Braille yang pada awalnya dianggap dapat digantikan dengan teknologi baru ternyata tidak sepenuhnya demikian. Hasil temuan peneliti di lapangan mengungkapkan bahwa pengguna DTB dalam memaparkan pengalamannya tetap menyertakan Braille sebagai sumber belajar lain.
Pada tahapan proses seleksi informasi, fakta bahwa pengguna akan memilih salah satu sumber informasi dan mengabaikan yang lain, tidaklah sepenuhnya berlaku. Siswa tunanetra dalam kesehariannya menggunakan sumber informasi dari Braille dan DTB secara bergantian sesuai dengan kebutuhan. Sebelum adanya DTB, siswa tunanetra yang dapat menggunakan Braille, dianggap telah memiliki kemampuan dasar untuk memperoleh ilmu pengetahuan. Braille digunakan untuk semua mata pelajaran di Sekolah Dasar Luar Biasa (SDLB) meskipun dengan keterbatasan, baik dari sisi jumlah, kondisi, maupun pengaturan penyimpanan yang minim.

Seiring dengan berkembangnya teknologi informasi dan komunikasi (TIK) yang memengaruhi hampir semua bidang kehidupan termasuk bidang pendidikan, hadirlah DTB sebagai salah satu solusi. Terlepas dari segala keterbatasannya, DTB sudah mulai diperkenalkan kepada siswa-siswa tunanetra yang hanya mempunyai disabilitas tunggal, artinya tidak dibarengi dengan ketidakmampuan di organ tubuh yang lain.

Para siswa yang telah menyelesaikan masa belajarnya di SDLB melanjutkan pendidikannya ke sekolah inklusi, sekolah yang menerapkan metode pembelajaran yang sama kepada semua anak, tidak terkecuali dengan anak-anak disabilitas. Artinya, secara kemampuan, siswasiswa tunanetra ditantang untuk mempunyai kapabilitas yang sama dalam menerima pelajaran dengan anak-anak berpenglihatan normal.

Pada sekolah inklusi, perbedaan cara mengakses sumber informasi menjadi persoalan tersendiri. Siswa tunanetra yang semula belajar melalui buku Braille yang mengandalkan indera pendengaran, kemudian dengan model komunikasi pesan visual harus mengandalkan indera pendengaran dengan model komunikasi pesan auditori karena harus belajar melalui DTB. 
Selain itu, siswa tunanetra juga dituntut memiliki kemampuan khusus untuk menguasai tomboltombol navigasi pada alat pemutar DTB.

Faktor berikutnya yang cukup memengaruhi lambat atau cepatnya seorang tunanetra beradaptasi dengan teknologi dengar ini adalah keluarga. Siswa tunanetra yang dari kecil terbiasa mendengarkan cerita dari orang tua atau anggota keluarga lainnya mempunyai kecepatan beradaptasi yang lebih baik.

Konten informasi, materi pelajaran yang dikemas ke dalam DTB tidak sertamerta membuat semua materi yang tersaji dapat diterima dengan baik oleh siswa tunanetra. Ada beberapa konten yang justru jika dipelajari dengan menggunakan DTB malah menjadi lebih sulit. DTB mempunyai ciri khas dan keunggulan tersendiri untuk konten yang spesifik, misalnya: bahasa Indonesia, bahasa asing, dan IPS yang mengandung tulisan yang panjang.

Pada tahapan interpretasi informasi, pengguna harus mampu memperhatikan berbagai tanda sebagai salah satu komponen penerimaan pesan. Agar pesan-pesan yang dikemas dan disajikan melalui DTB mempunyai arti dalam penafsirannya, informan membuat catatan pendukung yang menguatkan dengan menggunakan huruf Braille.

Faktor latar belakang, pengetahuan, dan minat juga turut memengaruhi seseorang dalam melakukan interpretasi makna. Informan adalah siswa penyandang tunanetra sejak lahir. Dilahirkan dari ibu dan ayah yang sama-sama tunanetra serta mempunyai adik yang juga menyandang tunanetra. Minat orang tua di bidang tulis-menulis membuat informan terbiasa dari kecil dengan kemampuan membaca dan mendengarkan cerita.

Tahapan selanjutnya setelah interpretasi adalah tahapan retensi. Dalam memori jangka pendek, informan mampu mengingat secara baik informasi yang bersifat sementara, seperti kata- kata istilah, angka-angka, dan penjelasan tentang definisi. Untuk memori jangka panjang, informan ternyata memiliki keterbatasan untuk mengingat informasi yang bersifat permanen, informan membutuhkan waktu yang lebih lama untuk memahami konten.

Dalam proses penerimaan informasi melalui $D T B$, pilihan untuk menggunakan Braille tetap tinggi. Dalam tahapan penyeleksian informasi dan pilihan terhadap sumber informasi, informan lebih cenderung memilih menggunakan Braille dibandingkan dengan DTB. Alasannya adalah karena penggunaan Braille lebih mudah, ekonomis, dan cepat. Artinya, saat menggunakan $D T B$, informan hanya mendengarkan orang bicara tentang materi, sementara ketika menggunakan buku Braille, informan dapat berinteraksi langsung dengan tulisan sehingga dirasakan lebih mengena.

\section{SIMPULAN DAN SARAN}

\section{Simpulan}

Berdasarkan hasil temuan dan pengamatan selama penelitian, dapat disimpulkan bahwa meskipun proses penerimaan informasi melalui media pembelajaran terlihat sebagai proses yang sederhana, ternyata hal ini melalui serangkaian proses yang cukup kompleks.

Pada tahapan seleksi informasi, informan dalam kesehariannya menggunakan sumber informasi dari Braille dan DTB secara bergantian sesuai dengan kebutuhan. Sebelum adanya $D T B$, siswa tunanetra menggunakan buku Braille untuk semua mata pelajaran di Sekolah Dasar Luar Biasa (SDLB).

Pada tahapan interpretasi informasi, informan menafsirkan materi pelajaran yang dikemas dan disajikan ke dalam DTB, dengan bantuan catatan menggunakan huruf Braille. Interpretasi makna juga sangat dipengaruhi oleh latar belakang, pengetahuan, dan minat. Informan 
lahir dari keluarga ibu dan ayah penyandang tunanetradengan adik yang juga penyandang tunanetra. Minat orang tua di bidang tulis menulis membuat informan terbiasa dengan kegiatan membaca dan menulis cerita sejak kecil sehingga berpengaruh terhadap minat informan terhadap pelajaran bahasa.

Pada tahapan retensi memori, informan mampu mengingat secara baik informasi yang bersifat sementara, seperti: kata-kata istilah, angka-angka, dan penjelasan tentang definisi. Untuk memori jangka panjang, informan ternyata memiliki keterbatasan untuk mengingat informasi yang bersifat permanen. Dalam kaitan ini, informan membutuhkan waktu yang lebih lama untuk memahami konten.

Dalam proses penerimaan informasi melalui DTB, pilihan untuk terus menggunakan Braille tetap tinggi. Dalam tahapan penyeleksian informasi dan pilihan terhadap sumber informasi, informan cenderung lebih memilih menggunakan Braille dibandingkan dengan DTB.

Beberapa alasan mengenai kecenderungan memilih buku Braille daripada DTB adalah karena dianggap lebih mudah, ekonomis, dan cepat. Jika menggunakan DTB, informan hanya mendengarkan orang bicara tentang materi. Berbeda dengan belajar melalui Braille di mana informan berinteraksi langsung dengan tulisan sehingga kegiatan belajar dirasakan menjadi lebih mengena.

Kesimpulan lain adalah bahwa hampir tidak ada materi yang sulit dipahami jika memakai
Braille. Belajar melalui Braille justru membuat informan dapat menggunakan indera perabanya secara optimal sehingga mampu mengingat materi pelajaran lebih cepat. Kondisi yang demikian ini diumpamakan seperti orang berpenglihatan normal yang mempunyai indera penglihatan yang lebih baik untuk mengingat. Belajar melalui Braille mempunyai kelemahan apabila digunakan untuk membaca tulisan yang agak panjang, di mana tangan akan terasa pegal karena harus terus bergerak dan membutuhkan konsentrasi tinggi.

\section{Saran}

Disarankan untuk melakukan penelitian eksperimen tentang bagaimana sebenarnya sebuah materi atau informasi/pesan diuji secara detail dan utuh agar diketahui kelebihan dan kekurangan dari kedua sumber informasi ini.

Mengingat penemuan Digital Talking Book ini belum sepenuhnya dikenalkan kepada siswasiswa penyandang disabilitas yang bersekolah di sekolah luar biasa, disarankan untuk melakukan penelitian tentang pemanfaatan media Digital Talking Book ini, baik di sekolah luar biasa maupun di sekolah inklusi.

Penelitian berikutnya yang disarankan untuk dilakukan adalah pengembangan model pembelajaran berbasis teknologi informasi dan komunikasi (TIK) yang sesuai dengan kondisi penyandang disabilitas dalam mengikuti kegiatan pembelajaran di sekolah inklusi.

\section{PUSTAKA ACUAN}

Fichten, C. S., et al., (2009). 'Disabilities and E-learning Problems and Solutions: An Exploratory Study', Educational Technology and Society, Vol. 12

Guba, E. G., \& Lincoln, Y. S. (1994). Competing paradigms in qualitative research. In N. K. Denzin \& Y. S. Lincoln (Eds.), Handbook of qualitative research. Thousand Oaks, CA: Sage.

Hujair AH. Sanaky (2009). Media Pembelajaran. Yogyakarta: Safiria Insania Press

Hunt, Morton (1982). The Universe Within; A New Science Explores The Human Mind. New York: Simon \& Schuster

Kartunet (2013). Simpang Siur Populasi Disabilitas di Indonesia. Diambil dari http://www.kartunet.com 
Lundh, A.H. (2013). Talking Books and Reading Children: Children Describing Their Use of Talking Books, Swedish Agency for Accessible Media

Neuman, W.L. (1997). Social Research Methods: Qualitative and Quantitative Approaches (3 $3^{r d}$ ed). Boston: Pearson Education, Inc (2006). Social Research Methods: Qualitative and Quantitative Approaches (6 $6^{\text {th }} \mathrm{ed}$ ). Boston: Pearson Education, Inc.

Petri, K. (2012). "Accessibility issues in e-books and e-book readers", in Polanka, S. (Ed.), Use and Management of Electronic Books, American Library Association, Chicago.

Ruben, Brent D. \& Stewart Lea P. (2006). Communication and Human Behavior (5 $5^{\text {th }}$ edition). Boston: Pearson Eucation, inc.

Sorongon, Ranil (2013). Digital talking books An Alternative Way of Educating Children With Disabilities of Their Rights: http://www.unescobkk.org/news/article

Tarsidi, Didi. (2005, March). Higher Education For Student With Visual Impairment In Indonesia. Paper presented at the $2^{\text {nd }}$ International Conference on Higher Education for Student with Disabilities, Waseda University Tokyo, Japan. 